\author{
К.Ю. Логаніхіна ${ }^{1,3}$, І.В. Бєлоус ${ }^{1}$, І.Б. Мельник', С. В. Дибкалюк ${ }^{2}$, В.Г. Несукай², І.С. Зозуля ${ }^{4}$ \\ 'Медичний центр «VitaCom діагностика», Київ \\ ${ }^{2}$ Комунальне некомерційне підприємство «Київська міська клінічна лікарня № 8» \\ ${ }^{3}$ Державна установа «Інститут ядерної медицини та променевої діагностики НАМн України», Київ \\ ${ }^{4}$ Національна медична академія післядипломної освіти імені П.Л. Шупика, Київ
}

\title{
Можливості мультиспіральної комп"ютерної томографії у діагностиці синдрому компресії хребтової артерії
}

Синдром компресії хребтової артерії - поліетіологічна нозологія, яка проявляється низкою клінічних симптомів. Мета - визначити варіанти патології та причини компресії хребтової артерії методом мультиспіральної комп'ютерної томографії - ангіографії. Виявлені фактори синдрому хребтової артерії розподілили на так звані інтравазальні (пов'язані з різними змінами судинної стінки) та екстравазальні (пов'язані зі змінами структур отворів поперечних відростків шийних хребців). В окрему групу виділили пацієнтів з аномаліями дуги аорти або пухлинами шиї, які призвели до розвитку синдрому компресії хребтової артерії. Проведені дослідження дозволили уточнити клінічні діагнози у пацієнтів із синдромом компресії хребтової артерії для вибору оптимального методу лікування.

Ключові слова: синдром компресії хребтової артерії, мультиспіральна комп'ютерна томографія, ротаційні проби.

\section{Вступ}

Синдром компресії хребтової артерії (СКХА) - комплекс симптомів, що виникають внаслідок порушення току крові у хребтових артеріях (ХА) (шифр М-47.0 в Міжнародній класифікації хвороб (МКХ)-10) (Дибкалюк С.В. та співавт., 2012; Барулин А.Е. и соавт., 2013). Питання діагностики і лікування СКХА в останні роки привертає дедалі більшу увагу дослідників, оскільки цей синдром є одним із найбільш значущих етіологічних факторів розвитку хронічних гемодинамічних порушень у вертебробазилярній системі (ВБС), особливо в осіб працездатного віку. На сьогодні встановлено, що близько $1 / 4$ інсультів і транзиторних ішемічних атак трапляються у BБC (Pirau L., Lui F., 2020). CKXA об'єднує комплекс церебральних, судинних, вегетативних синдромів, що виникають внаслідок ураження нервового (симпатичного) сплетіння XА, деформації її стінки або зміни просвіту і клінічно може проявлятися широким спектром симптомів, включаючи запаморочення, атаксію, дизартрію, дисфагію, прогресуючий або гострий параліч, втрату чутливості, а також тривалий час можливий безсимптомний перебіг, що призводить до недооцінки СКХА у клінічній практиці (Li Q. et al., 2019).

Методи візуалізації в діагностиці СКХА включають рентгенографію шийного відділу хребта, ультразвукову допплерографію (УЗДГ) судин шиї та головного мозку, магнітно-резонансну томографію, мультиспіральну комп'ютерну томографію - ангіографію (МСКТ-АГ) (Попелянский Я.Ю. (ред.), 2008; Хофер М., 2011; Ausman J.I. et al., 2018). При проведенні УЗДГ часто дослідження ХА виконують лише частково, їх не оглядають по всій довжині, а лише в початковому сегменті, функціональні позиційні проби, що проводяться, мають обмеження у клінічному застосуванні й недостатню інформативність (Гаевский Ю.Г. и соавт., 2019). Водночас методика МСКТ-АГ має вищу інформативність у діагностиці патологічних станів різних судин, зокрема судин шиї (Lu T. et al., 2017; Зозуля И.С. и соавт., 2018).

Мета - визначити варіанти патології та причини СКХА методом МСКТ-АГ.

\section{Об'єкт і методи дослідження}

Ретроспективно проаналізовані результати МСКТ-АГ у 149 пацієнтів, які звернулися у Медичний центр «VitaCom діагностика» з підозрою на СКХА. Дослідження проводили на 64-зрізовому комп'ютерному томографі «Philips» з робочою станцією «Vitrea». Використані МСКТ-протоколи сканування з мінімальним рівнем променевого навантаження, включаючи описану нами раніше методику: при положенні голови пацієнта прямо і з позиційними пробами (використовували максимальні повороти голови вправо або вліво; вибір сторони повороту голови базувався на результатах УЗДГ, скаргах пацієнта, даних неврологічного обстеження) (Дибкалюк С.В. та співавт., 2012; Зозуля И.С. и соавт., 2018; Зозуля І.С. та співавт., 2019). При візуалізації ХА насамперед розглядали сегмент $\mathrm{V}_{1}$ як найбільш варіабельний за гемодинамікою і судинними аномаліями $\mathrm{i} \mathrm{V}_{2}-$ як найбільш схильний до компресії внаслідок деформуючих змін шийного відділу хребта. Оцінювали такі параметри ХА: патологічну звивистість та її характер, діаметр просвіту, встановлювали фактори інтравазальної компресії - оклюзію просвіту ХА внаслідок органічного ураження інтими (гемодинамічнозначущого атеросклерозу, наслідків артеріїту) або тромбозу, або дисекції судинної артеріальної стінки. Порівняння вищезазначених параметрів ХА проводили при положенні голови прямо і після проведення позиційних проб.

\section{Результати та їх обговорення}

Хворі з підозрою на СКХА пред'являли різні скарги (рис. 1).

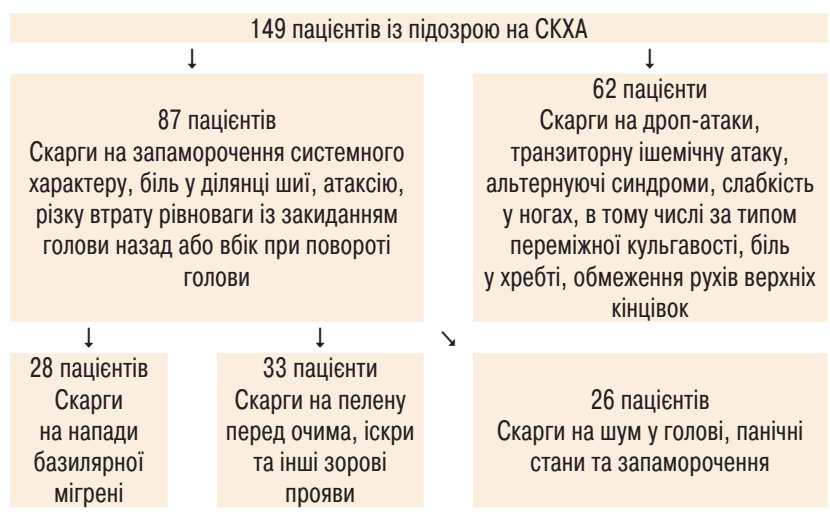

Рис. 1. Скарги пацієнтів із підозрою на СКХА

При оцінці результатів МСКТ-АГ серед факторів екстравазальної компресії ХА проаналізована частота виявлення так званих кісткових, або вертеброгенних, причин - дегенеративно-дистрофічних змін або наслідків травми шийного відділу хребта, що 


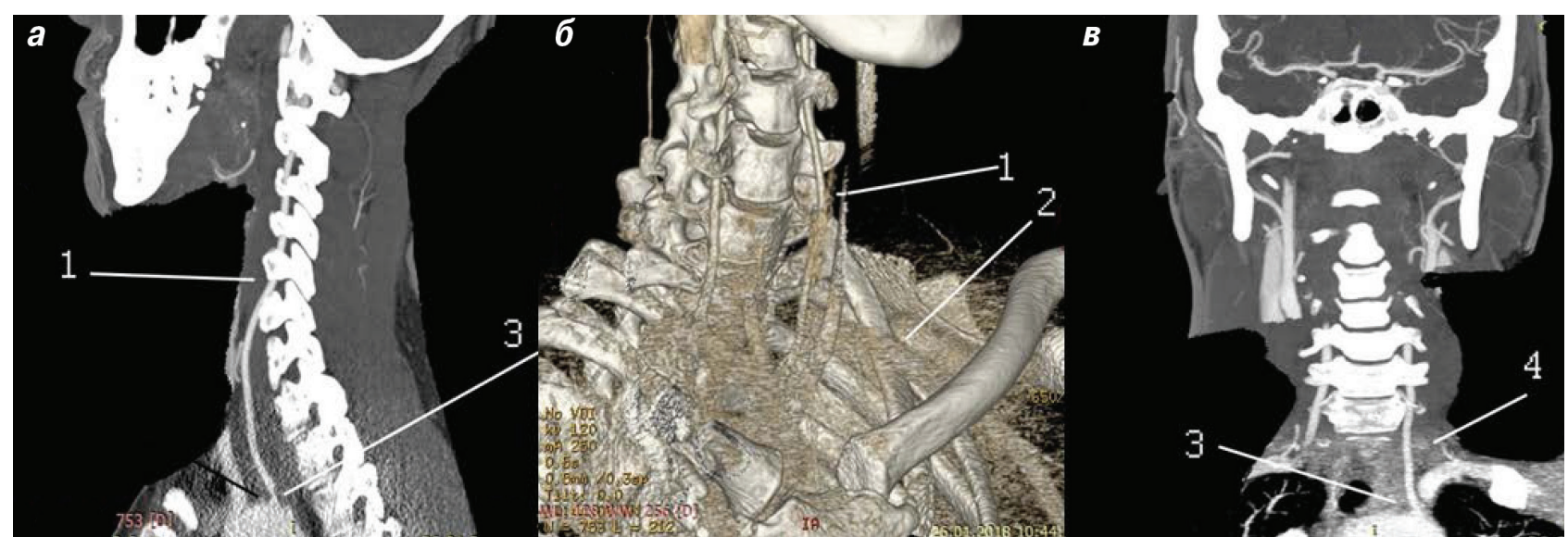

Рис. 2. Пацієнт В., 26 років. МСКТ-АГ судин шиї, пряме положення: $а$ - сагітальна, б - тривимірна, в - коронарна реконструкція. Відходження лівої ХА (1) безпосередньо від дуги аорти, а не від підключичної артерії (2), з атероматозними атеросклеротичними бляшками в гирлі (3), що викликають сумарне концентричне звуження просвіту судини. При цьому наявна патологічна звивистість лівої ХА у сегменті $\mathrm{V}_{1}$, чітко візуалізується у сагітальній проєкції, менш помітна у коронарній проєкції (4)

призвели до стенозу хребтового каналу та/чи міжхребцевих отворів (Кремер Ю., 2013; Ambali M.P., Jadhav S.D., 2017). В усіх пацієнтів за результатами МСКТ-АГ підтверджений діагноз СКХА. Більше ніж у половини виявлена патологічна звивистість ХА (рис. 2), найчастіше - V-подібна, у 69,8\% відбувалася зміна параметрів ХА при повороті голови (таблиця).

Таблиця. Частота змін ХА, за даними МСКТ-АГ у хворих на СКХА

\begin{tabular}{llcc}
\hline \multicolumn{2}{c}{ Параметри ХА } & $\begin{array}{c}\text { Абсолютне } \\
\text { число }\end{array}$ & $\%$ \\
\hline Патологічна звивистість & & 85 & 57,1 \\
Тип патологічної звивистості & V & 32 & 21,5 \\
& $\mathrm{C}$ & 29 & 19,5 \\
Гіпоплазія & $\mathrm{S}$ & 24 & 16,1 \\
Зміни параметрів ХА при повороті голови & 71 & 47,7 \\
Органічне ураження ХА & Тромбоз & 104 & 69,8 \\
& Артеріїт & 2 & 1,3 \\
Екстравазальна компресія & Атеросклероз & 3 & 2,0 \\
& Міотендогенні фактори & 15 & 10,1 \\
& Вертеброгенні фактори & 39 & 26,1 \\
& Аномалії дуги аорти & 82 & 55,0 \\
& Пухлини шиї & 23 & 15,4 \\
\hline
\end{tabular}

*Невертеброгенні, некісткового характеру чинники, які викликають здавлення судини у каналі шийного відділу хребта, насамперед при рухах голови.

Серед причин екстравазальної компресії найчастіше відзначали вертеброгенні (55,0\% хворих). Серед аномалій дуги аорти, що призвели до екстравазальної компресії XА у сегменті $\mathrm{V}_{1}$, безпосереднє відходження ХА від дуги аорти без змін самих судин дуги аорти виявлено у 15 пацієнтів (див. рис. 2), у 2 - з аневризмою загальної сонної чи підключичної артерії, у 1 - правобічна дуга аорти, рідкісні аномалії - truncus bicaroticus i Kommerell's diverticulum - у 3 і 2 пацієнтів відповідно (Loganikhina K.Y., Belous I.V., 2017).

Гіпоплазія ХА виявлена у 47,6\% пацієнтів (рис. 3).

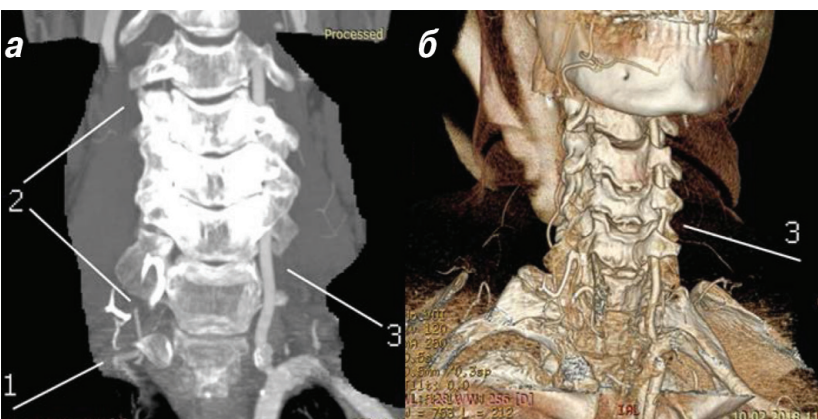

Рис. 3. Пацієнт А., 38 років. МСКТ-АГ судин шиї, пряме положення: $a$ коронарна, б - тривимірна реконструкція. Права ХА гіпоплазована, контрастується лише в початкових відділах сегмента $\mathrm{V}_{1}(1)$, в сегменті $\mathrm{V}_{2}$ - повна відсутність контрастування (2), ліва ХА вікарно гіпертрофована, має незмінені хід і контрастування (3)
Інтравазальна компресія як причина СКХА виявлена лише у 20 (13,4\%) пацієнтів, з них найчастіше - за наявності гемодинамічно значущого атеросклерозу (див. рис. 2), значно рідше (у 2 пацієнтів) - внаслідок тромботичної оклюзії (див. рис. 3). При цьому компенсованою інтравазальною компресією ХА вважали наявність тієї, при якій були артеріальні коллатералі від truncus thyrocervicalis або truncus costocervicalis, анастомозуючих з $V_{2}-V_{3}$ сегментами XА (у 3 пацієнтів). Зазначимо, що у кожної обстеженої особи виявлено як мінімум три МСКТ-ознаки, що підтверджували наявність СКХА (див. рис. 2).

Серед вперше візуалізованих об'ємних утворень шиї, які супроводжувалися клінічними симптомами СКХА, як внаслідок прямої інвазії XА, так і опосередковано через вплив на гілки шийного сплетення, у 2 пацієнтів виявлено бранхіогенну кісту шиї, по одному випадку - велику хемодектому, що інвазує парафарингеальний простір, нейрофіброматоз 2-го типу (рис. 4), метастатичне ураження шийного лімфовузла при випадково виявленому раку глотки (рис. 5).

Проблема своєчасної діагностики СКХА набуває актуальності у зв'язку з виникненням хронічних порушень, які суттєво знижують якість життя хворого і можуть призводити до інвалідності в будь-якому віці. Діагностика СКХА досить складна у зв'язку з поліморфізмом скарг і клінічної симптоматики.

Отримані результати узгоджуються з даними інших дослідників. Наявні кілька груп чинників, внаслідок яких може виникнути СКХА, серед яких - вроджені деформації (особливості будови) XА (патологічна звивистість, аномалії структури, ходу, перегини), оклюзивні захворювання артерій (атеросклероз, артеріїт, тромбоз, емболія), екстравазальні компресії ХА (здавлення їх кістковими аномаліями, ребрами, м'язами, остеофітами і суглобовими відростками шийних хребців, рубцями, пухлинами та ін.), часто вони поєднуються (Калашников В.И., 2007; Логвиненко А.В., 2016). СКХА частіше розвивається зліва внаслідок відходження лівої ХА безпосередньо від дуги аорти.

Найчастішими причинами виникнення CKXА є дегенеративно-дистрофічні зміни шийного відділу хребта, а факторами, що призводять до погіршення самопочуття хворого і появи скарг, $€$ різкі повороти або нахили голови (Choi K.D. et al., 2013; Neto A.C.L.N. et al., 2017). У проведеному нами дослідженні у пацієнтів із СКХА розвивалося запаморочення, коли голова була повернута в один або два боки, або нахилена в один бік, у деяких пацієнтів також відзначали шум у вухах, непритомність або нечіткість зору; динамічна ангіографія задокументувала типову СКХА у $70 \%$ пацієнтів.

Розвиток вертеброгенного CКХА визначається топографоанатомічним становищем XА; значна частина екстракраніального відрізка ХА проходить у рухомому кістковому каналі, утвореному отворами в поперечних відростках шийних хребців і рудиментами ребер, і екстравазальні фактори можуть ставати основними причинами недостатності кровообігу у ВБС (Vasuki A.K.M. et al., 2018; Zibis A. et al., 2018). 


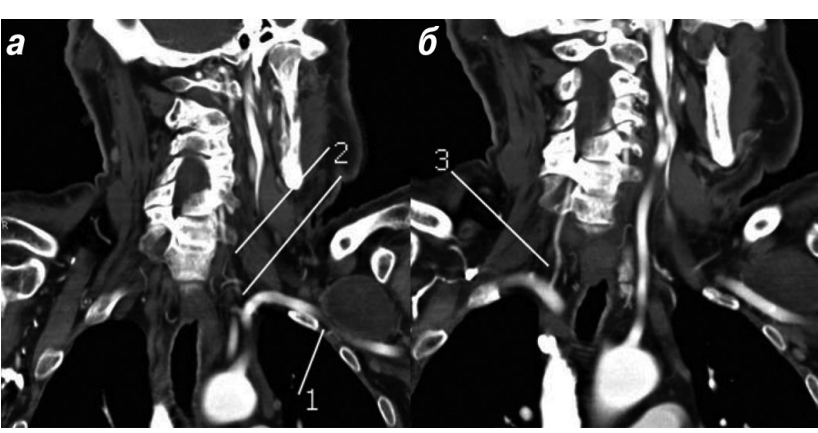

Рис. 4. Хворий А., 57 років. МСКТ-АГ судин шиї, положення: a - коронарна, б - тривимірна реконструкція. Нейрофіброматоз 2-го типу з великою лівобічною підключичною пухлиною, що здавлює ліву ХА (1), що супроводжується локальною частковою реканалізованою тромботичною оклюзією лівої XA на сегменті $V_{1}(2)$. Права XA (3) - 3 патологічною S-подібною звивитістю, різкими перегинами на її піках

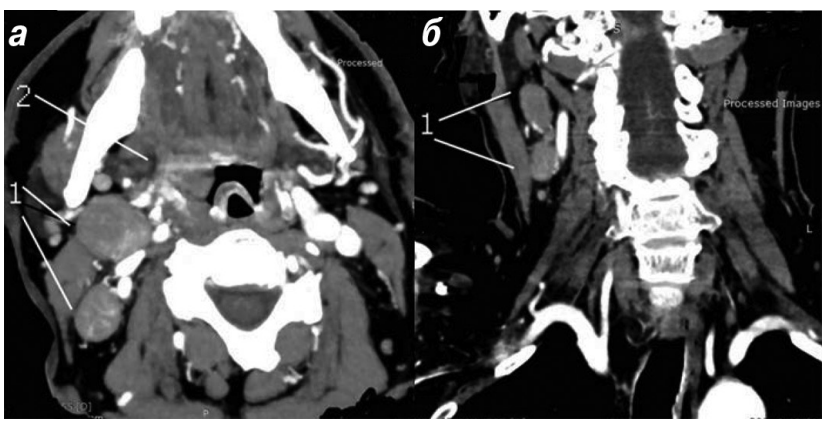

Рис. 5. Пацієнт 0., 70 років. МСКТ-АГ, аксіальна (а) проєкція в режим проєкції максимальних інтенсивностей, коронарна проєкція (б). Видно метастатичні шийні лімфовузли верхньої яремної та задньошийної групи внаслідок вперше виявленої пухлини ротоглотки в ділянці кореня язика праворуч і правої валлекули надгортанника (2)

У клінічній практиці маніфестація різних симптомів може призводити до помилкової діагностики функціонального (найчастіше - невротичного) розладу центральної нервової системи з подальшими неефективними спробами лікування лише седативними або анксіолітичними препаратами (Мурашко Н.К. та співавт., 2011; Kutty R.K. et al., 2020). Недооцінка ролі органічного фактора в розвитку СКХА призводить до хронізації симптомів.

Тяжкість своєчасної та точної діагностики СКХА зумовлюється тим, що патологічний процес проходить дві стадії і, якщо на першій, стадії функціональних порушень (головний біль із супутніми вегетативними порушеннями, запаморочення, розлади зору), причинний фактор протягом тривалого часу не зникає, то захворювання прогресує і настає друга, органічна (ішемічна) стадія, що виявляється транзиторними і стійкими порушеннями мозкового кровообігу (Калашников В.И., 2007; Зозуля И.С. и соавт., 2018; Carvalho V., 2018).

Щоб уникнути як гіпер-, так і гіподіагностики, для верифікації CKXА необхідно встановити факт компресійного впливу на XА, визначити, на якому рівні та при якому положенні голови і шиї відбувається їх здавлення (Perry J.J., Sharma M., 2019; Yun S. et al., 2020). Таким чином, лікування СКХА слід починати після встановлення точного діагнозу і виявлення причини компресії XА.

\section{Висновки}

1. За результатами МСКТ-АГ найчастішою причиною СКХА $€$ вертеброгенні чинники (у 55\% пацієнтів) і аномалії ходу ХА (у 57,1\% пацієнтів).

2. Проведення МСКТ-АГ з ротаційними пробами у $70 \%$ пацієнтів дозволяє виявити зміну параметрів функціонування XА.

3. МСКТ-АГ слід проводити всім пацієнтам із підозрою на СКХА для виявлення причини і верифікації діагнозу, що дозволяє визначити своєчасну оптимальну тактику ведення хворих і поліпшити показники ефективності лікування.

\section{Список використаної літератури}

Барулин А.Е., Курушина О.В., Мирошникова В.В. и др. (2013) Синдром позвоночной артерии: современные подходы к диагностике и лечению. Вест. ВолгГМУ, 4: 130-132.
Гаевский Ю.Г., Вебер В.Р., Захарова В.М. и др. (2019) Ультразвуковые особенности морфологии второго сегмента позвоночных артерий и их гемодинамики. Лучевая диагностика и терапия, 1: 33-38 (https://doi.org/10.22328/20795343-2019-10-1-33-38)

Дибкалюк С.В., Черняк В.А., Герцен Г.І. (2012) Клінічний перебіг та особливості діагностики та синдрому компресії хребтової артерії. Наук. вісн. Ужгород. ун-ту, 2(44): 44-46.

Зозуля И.С., Несукай В.Г., Белоус И.В. и др. (2018) Структурно-морфометрическая характеристика сосудов вертебрально-базилярного бассейна и отверстий поперечных отростков шейных позвонков по данным мультиспиральной компьютерной томографии у пациентов с остеохондрозом шейного отдела позвоночника, перенесших транзиторную ишемическую атаку. Экстрен. мед., 1: $56-67$.

Зозуля І.С., Несукай В.Г., Логаніхіна К.Ю. та ін. (2019) Спосіб визначення наявності динамічної компресії хребтової артерії на сегментах $\mathrm{V}_{1}, \mathrm{~V}_{2}$ у хворих із порушенням кровообігу у вертебробазилярному басейні. Бюл. № 2, № 131829.

Калашников В.И. (2007) Синдром позвоночной артерии. Тherapia, 10:31-33.

Кремер Ю. (2013) Заболевания межпозвонковых дисков. Пер. с англ. МЕДпресс-информ, Москва, 472 с.

Логвиненко А.В. (2016) Анатомо-физиологические предпосылки развития синдрома позвоночной артерии. Міжнар. мед. журн., 4: 73-76.

Мурашко Н.К., Попов О.В., Галуша А.І. (2011) Шийна мігрень або синдром компресії хребтової артерії. Мистецтво лікування, 2(78): 30-33.

Попелянский я.Ю. (ред.) (2008) Ортопедическая неврология (вертеброневрология): Руковод. для врачей. 4-е изд. МЕДпресс-информ, Москва, 672 с

Хофер М. (2011) Компьютерная томография. Базовое руководство. Медицинская литература, Москва, 232 с.

Ambali M.P., Jadhav S.D. (2017) Anatomical variations in foramen transversarium of typical cervical vertebrae and its clinical significance. Int. J. Anat. Res., 5(1): 3426-3429. doi.org/10.16965/ijar.2016.494.

Ausman J.I., Liebeskind D.S., Gonzalez N. et al. (2018) A review of the diagnosis and management of vertebral basilar (posterior) circulation disease. Surg. Neurol. Int., 9: 106. doi: 10.4103/sni.sni_373_17.

Carvalho V. (2018) Vertebrobasilar stroke. Int. J. Clin. Neurosci. Mental Health, 5(Suppl. 2): L4.

Choi K.D., Choi J.H., Seo J.D. et al. (2013) Rotational vertebral artery occlusion: mechanisms and long-term outcome. Stroke, 44(7): 1817-1824. doi.org/10.1161/ STROKEAHA.113.001219.

Kutty R.K., Yamada Y., Takizawa K., Kato Y. (2020) Medullary Compression Due to Ectatic Vertebral Artery - Case Report and Review of Literature. J. Stroke Cerebrovasc. Dis., 29(1): 104460. doi.org/10.1016/i.jstrokecerebrovasdis.2019.104460.

Li Q., Xie P., Yang W. -S. et al. (2019) Vertebral Artery Compression Syndrome. Front. Neurol., 10: 1075. doi: 10.3389/fneur.2019.01075.

Loganikhina K.Y., Belous I.V. (2017) Поєднання Kommerell's diverticulum та truncus bicaroticus - випадок з практики. Radiation Diagnostics, Radiation therapy, 3: 88-91.

Lu T., Chinnadurai P., Anaya-Ayala J.E., Diaz O.M. (2017) DynaCT angiography for the diagnosis of bilateral bow hunter's syndrome. Interv. Neuroradiol., 23(1): 73-78. doi: 10.1177/1591019916673221.

Neto A.C.L.N., Bittar R., Gattas G.S. et al. (2017) Pathophysiology and Diagnosis of Vertebrobasilar Insufficiency: A Review of the Literature. Int. Arch. Otorhinolaryngol., 21(3): 302-307. doi: 10.1055/s-0036-1593448.

Perry J.J., Sharma M. (2019) Computed tomography angiography to identify the cause of a transient ischemic attack versus irradiating patients without cause (or even a TIA). CJEM, 21(3): 313-314. doi: 10.1017/cem.2019.27.

Pirau L., Lui F. (2020) Vertebrobasilar Insufficiency (https://www.ncbi.nlm.nih. gov/books/NBK482259/)

Vasuki A.K.M., Jamuna M., Nirmaladevi M. et al. (2018) An osteological study of foramen transversarium of cervical vertebrae and its clinical significance. Int. J. Anat. Res., 6(1.2): 4906-4913. doi.org/10.16965/ijar.2017.505.

Yun S., Lee J.Y., Kwon E. et al. (2020) Compression of both vertebral arteries during neck extension: a new type of vertebral artery compression syndrome. J. Neurol., 267(1): 276-278. doi: 10.1007/s00415-019-09576-7.

Zibis A., Mitrousias V., Galanakis N. et al. (2018) Variations of transverse foramina in cervical vertebrae: what happens to the vertebral artery. Eur. Spine J., 27(6): 1278-1285. doi.org/10.1007/s00586-018-5523-2.

\section{Возможности мультиспиральной компьютерной томографии}

\section{в диагностике синдрома компрессии} позвоночной артерии

\section{Е.Ю. Логанихина, И.В. Белоус, И.Б. Мельник, С.В. Дыбкалюк, В.Г. Несукай, И.С. Зозуля}

Резюме. Синдром компрессии позвоночной артерии - полиэтиологическая нозология, проявляющаяся рядом клинических симптомов. Цель - определить варианты патологии и причины компрессии 


\section{ОРИГІНАЛЬНІ ДОСЛІДЖЕННЯ}

позвоночной артерии методом мультиспиральной компьютерной томографии - ангиографии. Выявленные факторы синдрома позвоночной артерии разделили на так называемые интравазальные (связанные с различными изменениями сосудистой стенки) и экстравазальные (связанные с изменениями структур отверстий поперечных отростков шейных позвонков). В отдельную группу выделили пациентов с аномалиями дуги аорты или опухолями шеи, приведшими к развитию синдрома компрессии позвоночной артерии Проведенные исследования позволили уточнить клинические диагнозы у пациентов с синдромом компрессии позвоночной артерии для выбора оптимального метода лечения.

Ключевые слова: синдром компрессии позвоночной артерии, мультиспиральная компьютерная томография, ротационные пробы.

\section{Possibilities of multispiral computed tomography in the diagnosis of vertebral artery compression syndrome \\ E.Yu. Loganikhina, I.V. Belous, I.B. Melnik, S.V. Dybkalyuk, V.G. Nesukay, I.S. Zozulya}

Summary. Compression syndrome of the vertebral artery is a polyetiological nosology, manifested by a number of clinical symptoms. The aim is to determine the pathology variants and causes of compression of the vertebral artery using multislice computed tomography - angiography. The identified factors of the vertebral artery syndrome were divided into the so-called intravasal (associated with various changes in the vascular wall) and extravasal (associated with changes in the structures of the holes of the transverse processes of the cervical vertebrae). A separate group was assigned to patients with anomalies of the aortic arch or neck tumors, which led to the development of the syndrome of compression of the vertebral artery. The studies carried out made it possible to clarify the clinical diagnoses in patients with vertebral artery compression syndrome in order to choose the optimal method of treatment.

Key words: vertebral artery compression syndrome, multispiral computed tomography, rotary tests.

\section{Адреса для листування:}

Зозуля Іван Савович

04112, Київ, вул. Дорогожицька, 9

Національна медична академія

післядипломної освіти імені П.Л. Шупика,

кафедра медицини невідкладних станів

E-mail: nmapo.emergency@gmail.com

Одержано 10.11.2020 